\title{
Livestock Export from Adama Quarantine Stations: Comparing Management and Biosecurity of Feedlots before Live Animal Export, DireDawa, Ethiopia
}

\author{
Jirata Shiferaw $^{1} \quad$ Wesenu Berhanu ${ }^{2}$ \\ 1.Addis Ababa University, College of Veterinary Medicine and Agriculture, Bishoftu, Ethiopia \\ 2.Haromaya University, College of Veterinary Medicine and Agriculture, DireDawa, Ethiopia
}

\begin{abstract}
This study was conducted to characterize and identify husbandry practice and major constraints of feedlot industries in Adama quarantine area. Three feedlot farms were used to collect data to compare management and biosecurity of each feedlot and determine the impact of improper animal handling on animal export from Ethiopia. Questionnaire data collected was coded and entered in to Microsoft Excel spread sheet and was analyzed by using SPSS version 16.0 software. Questionnaire survey has been conducted on 40 of the quarantine workers which include the management team, veterinarian in charge and daily laborers. Among the total of 40 people $62.5 \%(25 / 40)$ answers the animal injured found in the quarantine whether they are due to transportation or incomplete management found in the feedlot. When we see the number of died animals in each quarantine stations it is quite different in number. For example, in Koshe and Wanji quarantine stations the number of died animals are $11(2.2 \%)$ and $12(0.75 \%)$ respectively but the number died animals in both quarantine stations were significantly different when comparing by their number of animals found in the farm. According to the respondents and statistical evaluation rate the biosecurity in three feedlots scarcity or totally absent of feedlot requirements leads diseases to cattle which in turn constraint the live animal export and decrease the requirement of Ethiopia's livestock in import countries. As statistical evaluation shows the percentage of injury, no isolation of new arrival and sick animals, feed disorder, improper storage of feed, problems in the farm including scarcity of materials, absence of vaccination and contact of species of animals that were not the member of the species those in feedlot were significant reason in study area. Individually all person should take responsibility to present quality livestock for export requirement.
\end{abstract}

Keywords: Adama, feedlot, livestock export, management and biosecurity, quarantine, questionnaire survey, Ethiopia

DOI: $10.7176 /$ ALST/83-04

Publication date: November $30^{\text {th }} 2020$

\section{INTRODUCTION}

Ethiopia ranks first in livestock resources in Africa with the potential to export substantial numbers of live animals and meat products. However, various constraints continue to hinder international trade to destinations of choice turning the country into a major supplier of live cattle, camels and shoats to its neighboring countries (Aklilu, 2008). Feedlot based livestock export in Ethiopia is currently affected by biocontainment, awareness of the actors and poor biosecurity measures in feedlots, those feedlots are venerable for introduction and spread of transboundary animal diseases (Alemayehu, 2012; Alemayehu et al., 2012).

To improve the competitiveness of live animals export from Ethiopia, tremendous interventions in the coordination of livestock marketing activities and in the provision of market support services are needed. If livestock producers and exporters are to be competitive in both domestic and international markets, their value supply chains need to be more efficient and more effective. This will require not only the competitiveness of individual but also improving the efficiency of all its elements from production to processing, handling, distribution, and marketing. Hence, there is a need for analyzing the value chains for live animal exports (Hailemariam, 2008).

There is great potential to increase the export of live animals to the nearby Middle Eastern markets. All those involved in the production, processing and marketing must adopt improved practices in production, transportation and processing of products to maintain and increase market share. It is imperative that animal producers, buyers and processors be aware of the status and requirements of the export market. Further, appropriate training should be provided to all stakeholders to help them meet market requirements and maximize the benefits from the growing meat and live animal export trade (Desta, 2011).

The need to strengthen veterinary services through public and private good is becoming more apparent in light of the recurring bans being imposed by importing countries despite to initiative revive livestock from Ethiopia (Hussein, 2010). Our country has long way to go to bring the status of veterinary services to internationally acceptable standards given the ever increasing stringent rules and regulations being formulated by actors such as OIE and EU. At this stage, Ethiopia is formulating policy initiatives to address the issue using 
different approaches (Aklilu, 2008).

Ethiopians have been engaged in livestock production and trade for centuries and much of the business of livestock production is not that much different today than what it has been over the years. Yet in hypercompetitive global economy that demands instantaneous changes to product design and ever higher standards of quality and supply, gaining and maintaining market share, even in one own market is more challenging than ever. Ethiopia has a number of livestock value chain market opportunities that if realized will power the growth the livestock industry and value chain as well as the overall economy. Currently, Ethiopia exports livestock through formal market channels nearly a million head of animals per year and those numbers are increasing by $15-25 \%$ per year. This rapid rise in the export of live animals creates a conundrum for the country because by lowering the number of live animals exported, Ethiopia would see a reduction in the overall revenue attributed to live animal exports (USAID, 2013).

Animal health, welfare and biosecurity are important at all stages of the livestock production chain. Each can have potentially adverse impacts on productivity if managed poorly and because producers have a duty of care to their livestock. If not upheld, these issues have the potential to reflect badly on the whole industry (Carlson, 1998).

Biosecurity programs for cattle, sheep and goat industries are designed to prevent the spread of infectious disease and contain disease outbreaks when they occur (Spencer, 1996). An important biosecurity action on ranches is to separate cattle by age or production groups. Facilities should be cleaned and disinfected appropriately between groups. Visit with your veterinarian about specific isolation management procedures and how they can be applied to control targeted diseases (Grant, 1998). Traffic control includes traffic onto operation and traffic patterns within the operation. It is important to understand traffic includes more than vehicles. All animals and people must be considered. The degree of control will be dictated by the biology and ecology of the infectious organism being addressed and the control must be equally applied (Grant, 1998).

Quarantine inspector should make sure that facilities are properly designed and in good repair i.e. the owner of the quarantine should make sure that supplies and needs are ready before the animals arrive. Properly designed and maintained facilities are important factors that influence proper care of newly arriving animals. If animals cannot flow through the facilities with ease, the quarantine inspector should analyze the situation and make changes (MoA, 2010). Early detection of sickness and early treatment are paramount to a successful quarantine program. The most important factor that will influence the ability of quarantine inspectors to find sick animals is the amount of time they devote to find sick animal every morning. When feeding animals, adapting newly arriving animals from the range to a dry lot ration without inducing gut irritation and acidosis is a major factor in preventing diseases in quarantine facilities and the quarantine facility nutritionist should typically start cattle on a moderate energy, total mixed, dry ration offered in two to three split feedings during the first five to seven days after processing (MoA, 2010).

To improve the competitiveness of live animals export from Ethiopia tremendous interventions in the coordination of livestock marketing activities and in the provision of market support services are needed. To attain efficient use of the sector, to improved export performance cost-effective marketing channels and coordinated supply chains, which reduce the transaction costs among different actors along the supply chain are crucial (Getachew, 2008)

Therefore, the objectives of this thesis include:

a) To compare management and biosecurity of feedlots

b) To determine various numbers of internal weaknesses in feedlot which constraints live animal exports from Ethiopia.

The present study investigates the poor management practices of Adama area feedlot animals for export and the poor biosecurity by quarantining all age groups of animals all together and slaughtering of sick animals for local consumptions.

\section{MATERIALS AND METHODS Description of Study Area}

The study was conducted in Adama Quarantine stations of East Shoa zone of Oromia Regional state. Adama town is found $99 \mathrm{~km}$ East of Addis Ababa with varying ranges of altitude from 1400-2300meter above sea level. It receives annual rain fall of $600-1150 \mathrm{ml}$ with a mean maximum and minimum temperature of 12 and $33 \mathrm{c}^{0}$ respectively. There are about 356,112 livestock. Adama is dominated by smallholder producers who utilize an average of 1.75 hectares of land per household. The area experiences three seasons: kiremt (rainy), meher (winter) and bega (spring). The main rainfall usually occurs from late bega (June) to late kiremt (September). The main crops grown are Tef (Eragrostistef), wheat (Triticumaestivum), Maize (Zeamays), Barley (Hordeumvulgaris), Beans (Phaseolusvulgaris) and naturally occurring pasture-tropical grasses are also grown. Cattle, sheep, goats, donkeys and poultry are kept by the majority of households in the area. The majority of household income comes from agriculture. Livestock and labor (off-farm) activities contribute the remaining 
income. There are different means of transportation in the town of which horses drawn carts are preferably used for loads in accessible to taxis and because of relatively lower charges, specially the place where taxis are not concerted. The area is the major quarantine stations for livestock export (Addisu, 2012).

\section{Study Animal}

Feedlot animals that are found in Adama Quarantine stations was conducted as study animals in considering their management and biosecurity under taken at quarantine place before export.

\section{Study Design}

Study Type

A cross-sectional study was conducted from November 2013 to March 2014 to determine the handling system of feedlot animals in quarantine that are going to be exported. Also study was identifying these handling systems whether or not has negatively impact on livestock export from Ethiopia as a whole.

\section{Sample Size Determination}

Three cattle feedlots which contain a total number 3050 cattle were chosen and compared for their management and biosecurity under taken in each farm.

\section{Study Methodology}

Primary data were collected using questionnaire through interview and discussion with the feedlot operators.

Physical observation of commercial farms was also used as an instrument to collect data during the study. In addition, secondary information was gathered from literature reports.

Visiting the Farm or Quarantine place

The methodology for collecting data was largely through intensive one-on-one interviews and focus group discussion. To observe the management and biosecurity undergo at quarantine place, activity in and around the farm or quarantine was visited.

\section{Questionnaire survey}

Data on the types of livestock species used for feedlot, pattern of livestock preferences, breeds of cattle, fattening duration, feed resources, feeding procedure and constraints and housing of commercial fattening were collected from the commercial fatteners Using well constructed questionnaire format, an assessment was made to generate data on general aspects of feedlot animals with particular emphasis on management and biosecurity problems at quarantine place.

\section{Data analysis}

Questionnaire data collected was coded accordingly entered in to Microsoft Excel spread sheet and was analyzed by using SPSS version 16.0 soft ware.

\section{RESULTS}

\section{Questionnaire investigation}

Questionnaire survey has been conducted on 40 of the quarantine workers which include the management team, veterinarian in charge and daily laborers. The structured questionnaire aimed to assess the basic understanding of the groups in relation to management and biosecurity of the feedlot

\section{Visiting the farm or quarantine stations}

During the visit of three quarantine stations that conducted from November 2013 to March 2014 which are individually export cattle to different countries, namely: Sudan, Lebanon, Saudi Arabia, Egypt, Yemen, Jordan, Oman, Dubai and Beirut which all are Muslim countries. Activities in and around the quarantine center were observed including construction of the feedlot site.

Table1: Intensity of wound in each feedlot

On new arriving and stayed animals in feedlots, there are numerous wounds which are kept according to their intensity.

\begin{tabular}{llllll}
\hline Quarantine stations & Mild & Moderate & sever & total & Persantage $(\%)$ \\
\hline Wanji & 50 & 40 & 27 & 117 & 10.63 \\
MedtechEthiopia & 92 & 70 & 52 & 214 & 23.8 \\
Koshe & 102 & 72 & 67 & 241 & 43.81 \\
\hline
\end{tabular}

Early detection of sickness and early treatment are paramount to a successful quarantine program. During the study time percent of different activities found in each quarantine stations were categorized in the following table. 
Table2: percent of diseases and different activities in all feedlots

\begin{tabular}{|c|c|c|c|c|c|c|c|c|c|}
\hline Factors & Origion & $\begin{array}{l}\text { No of } \\
\text { sample }\end{array}$ & $\begin{array}{l}\text { Respiratory } \\
\text { disease Test } \\
+ \text { ve }\end{array}$ & $\begin{array}{l}\text { Infectious and non- } \\
\text { infectious disease } \\
\text { Test +ve }\end{array}$ & $\begin{array}{l}\text { Percentage } \\
\text { of } \\
\text { respiratory } \\
(\%)\end{array}$ & $\begin{array}{l}\text { Percentage } \\
\text { of infectious } \\
\text { and non- } \\
\text { infectious } \\
(\%)\end{array}$ & $\mathrm{X}^{2}$ & $\begin{array}{l}\text { D } \\
\text { f }\end{array}$ & $\begin{array}{l}\text { P- } \\
\text { value }\end{array}$ \\
\hline \multirow[t]{3}{*}{ Quarantine } & Wanji & 1099 & 1099 & 0 & 43.1 & 0 & 2.54 & 2 & 0.000 \\
\hline & Koshe & 549 & 0 & 549 & 0 & 21.6 & & & \\
\hline & Med-tech & 899 & 899 & & 35.3 & 0 & & & \\
\hline Total & 2547 & 1998 & 549 & 78.4 & 21.6 & & & & \\
\hline Isolation of & No & 1448 & 899 & 549 & 35.3 & 21.6 & 5.31 & 1 & 0.000 \\
\hline diseased & Yes & 1099 & 1099 & 0 & 43.1 & 0 & & & \\
\hline Total & 2547 & 1998 & 549 & 78.4 & 21.6 & & & & \\
\hline \multirow[t]{2}{*}{ Feeding } & Straw & 1998 & 1998 & 0 & 78.4 & 0 & 2.54 & 1 & 0.000 \\
\hline & $\begin{array}{l}\text { Formulated } \\
\text { feed }\end{array}$ & 549 & 0 & 549 & 0 & 21.6 & & & \\
\hline Total & 2547 & 1998 & 549 & 78.4 & 21.6 & & & & \\
\hline Feed storage & Two week & 1099 & 1099 & 0 & 43.1 & 0 & 5.31 & 1 & 0.000 \\
\hline period & Three week & 1448 & 899 & 549 & 35.3 & 21.6 & & & \\
\hline Total & 2547 & 1998 & 549 & 78.4 & 21.6 & & & & \\
\hline \multirow[t]{3}{*}{$\begin{array}{l}\text { Problem } \\
\text { encountered }\end{array}$} & $\begin{array}{l}\text { Shortage of } \\
\text { feed and } \\
\text { water }\end{array}$ & 899 & 899 & 0 & 35.3 & 0 & 2.54 & 2 & 0.000 \\
\hline & Quality & 1099 & 1099 & 0 & 43.1 & 0 & & & \\
\hline & All problem & 549 & 0 & 549 & 0 & 21.6 & & & \\
\hline Total & 2547 & 1998 & 549 & 78.4 & 21.6 & & & & \\
\hline № $\quad$ of & Eight & 1099 & 1099 & 0 & 43.1 & 0 & 5.31 & 1 & 0.00 \\
\hline $\begin{array}{l}\text { watering and } \\
\text { feeding } \\
\text { trough }\end{array}$ & $<6$ & 1448 & 899 & 549 & 35.3 & 21.6 & & & \\
\hline Total & 2547 & 1998 & 549 & 78.4 & 21.6 & & & & \\
\hline Strategic & Yes & 1998 & 1998 & 0 & 78.4 & 0 & 2.54 & 1 & 0.000 \\
\hline $\begin{array}{l}\text { plan for } \\
\text { vaccination }\end{array}$ & No & 549 & 0 & 549 & 0 & 21.6 & & & \\
\hline Total & 2547 & 1998 & 549 & 78.4 & 21.6 & & & & \\
\hline Vaccines & FMD only & 549 & 0 & 549 & 0 & 21.6 & 2.54 & 2 & 0.000 \\
\hline \multirow[t]{2}{*}{ given } & All & 1099 & 1099 & 0 & 43.1 & 0 & & & \\
\hline & Some & 899 & 899 & 0 & 35.3 & 0 & & & \\
\hline Total & 2547 & 1998 & 549 & 78.4 & 21.6 & & & & \\
\hline Contact with & Yes & 1448 & 899 & 549 & 35.3 & 21.6 & 5.31 & 1 & 0.000 \\
\hline other animal & No & 1099 & 1099 & 0 & 43.1 & 0 & & & \\
\hline Total & 2547 & 1998 & 549 & 78.4 & 21.6 & & & & \\
\hline
\end{tabular}

Biosecurity and management observed in each feedlot during visiting of the farm. During visiting of the quarantine station every activity in and around the feedlot were collected by comparing three feedlots namely Wanji, Med-tech Ethiopia and Koshe feedlot stations which are mentioned in the following table. 
Table3: Biosecurity and management of each feedlot

\begin{tabular}{|c|c|c|c|c|}
\hline \multirow[t]{2}{*}{ Number } & \multirow[t]{2}{*}{ Management and biosecurity } & \multicolumn{3}{|c|}{ Quarantine stations } \\
\hline & & Wanji & Med-tech Ethiopia & Koshe \\
\hline 1 & Feed hygiene & Good & Moderate & Poor \\
\hline 2 & Watering & Good & Poor & Poor \\
\hline 3 & Entrance restriction & Poor & poor & Poor \\
\hline 4 & Isolation of new arrival & Moderate & poor & Poor \\
\hline 5 & Isolation of sick animals & Good & moderate & Poor \\
\hline 6 & Minimize visitor entrance & Moderate & moderate & Moderate \\
\hline 7 & Have disinfectant areas & Poor & poor & Poor \\
\hline 8 & Feed and water contamination with feces and urine & Good & moderate & Poor \\
\hline 9 & Equipment cleaning & Moderate & poor & Poor \\
\hline 10 & $\begin{array}{l}\text { Contact with other animals } \\
\text { YARD/STALL }\end{array}$ & Good & poor & Moderate \\
\hline 11 & Wind proof & Poor & poor & Poor \\
\hline 12 & Predatory proof & Good & moderate & Modearate \\
\hline 13 & $\begin{array}{l}\text { Enough space } \\
\text { TREATMENT }\end{array}$ & Good & poor & Poor \\
\hline 14 & Curative treatment & Moderate & poor & Poor \\
\hline 15 & Deworming & Good & good & Good \\
\hline 16 & Vaccination & Good & moderate & Moderate \\
\hline 17 & Handling during for treatment and vaccination & Good & moderate & Poor \\
\hline
\end{tabular}

From starting unloading of the first animal into the premises and ends with the departure of the last animal from the premises whether or not passed as fit for export, livestock must be held insecure premises for a sufficient period of time to meet importing country requirements. Preparation of livestock must comply with this Standard. Livestock must also be inspected and deemed fit to travel before leaving the premises. During the farm visit, the following things are observed whether they are present or absent

Table 4: Absence and presence of feedlot requirements

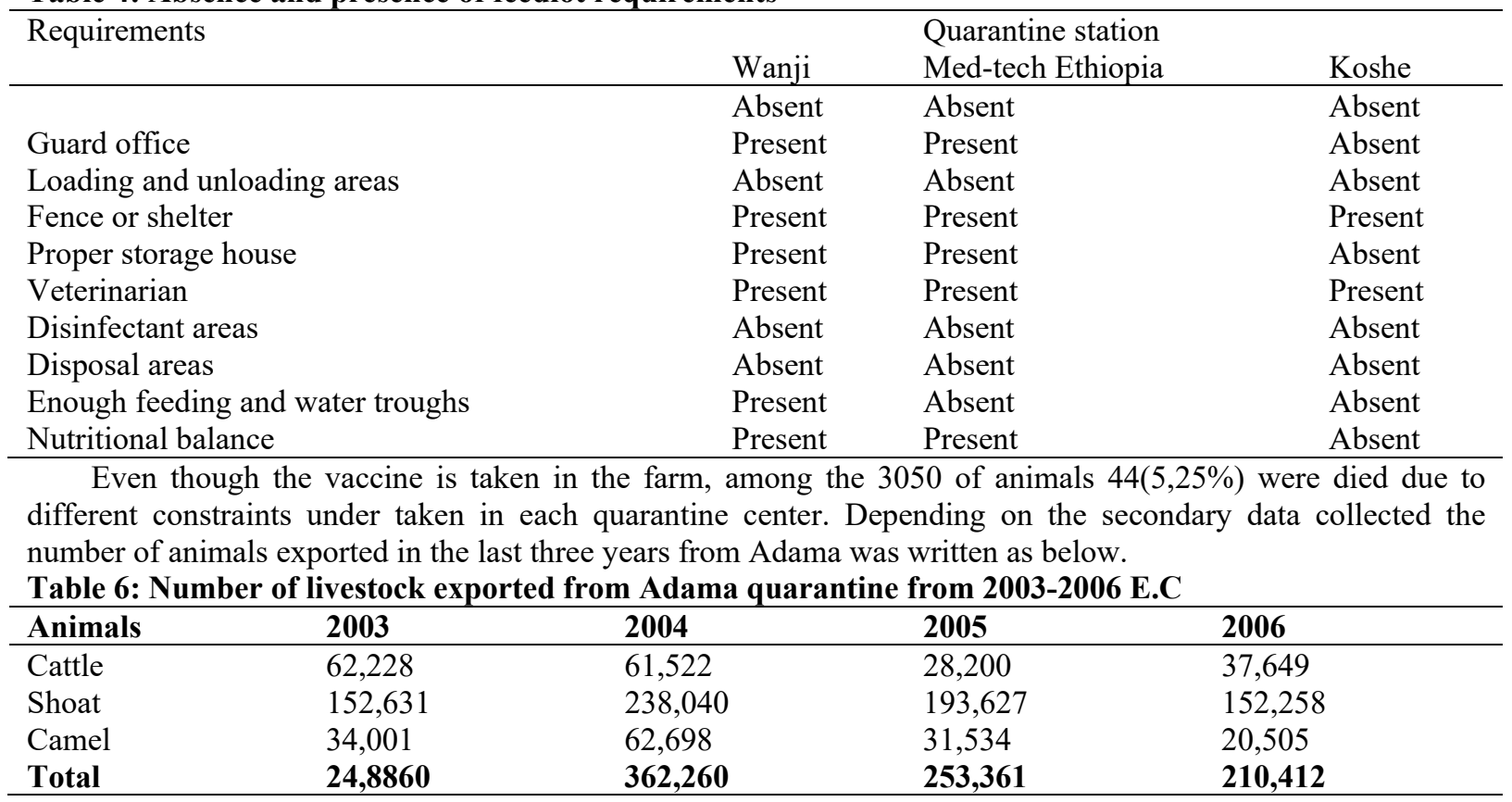

\section{DISCUSSION}

Among the total of 40 people $62.5 \%$ (25/40) answers the animal injured found in the quarantine whether they are due to transportation or incomplete management found in the feedlot. According to World Organization for Animal Health (OIE), animals should be transported by designated trucks that don't impede good handling during transport. None of the live animal exporters have dedicated trucks for transport of live animals in Ethiopia. Hence, all live animal exporters and traders depend on the ordinary trucks for transporting live animals, despite the fact that the ordinary trucks have various limitations. The drivers and assistants of such ordinary trucks do not have the necessary training and orientation for proper handling of animals during transport (Belachew and Dugasa, 2006). 
From 40 workers of the quarantine stations, 35 or $87.5 \%$ reply that vaccine and treatment have been taken starting from animal entrance in quarantine. Among three feedlots $43.1 \%$ of vaccine was given only in Wanji quarantine station while in the rest two were less comparatively. This may help animals to resist diseases that occurred due to sanitation and contamination because in some feedlot sanitation and management of feedlot is poor regarding to the rule and regulation of the animal quarantine station. In Koshe and Med-tech Ethiopia there is contamination of water and feed with animal feces and urine, also there was contact of other animals those in quarantine which have its own effect on the healthy of animals in quarantine.

Despite current levels of advancement in diagnostic tests, import/export programs of animals still incorporate a formal quarantine period in order to effectively prevent livestock disease introduction and spread between countries. In order to eliminate the possibility of spreading animal disease into importing countries, quarantine inspectors will routinely apply quarantine guideline to observe, isolate, treat and test export animals coming from various parts of the country (MoA, 2010).

Sick animals should isolate from healthy one to reduce the risk of disease expansion in the farm. The result shows that $83.3 \%$ of the workers of Wanji quarantine center understood the effect of isolation of sick animals with that healthy.

When we see the number of died animals in each quarantine stations it is quite different in number. For example, in Koshe and Wanji quarantine stations the number of died animals are 11(2.2\%) and 12(0.75\%) respectively but the number died animals in both quarantine stations were significantly different when compared by their number of animals found in the farm. So this may be due to the difference of management and biosecurity under taken in both quarantine.

According to the respondents and statistical evaluation rate the biosecurity in three feedlots scarcity or totally absent of what feedlot should have leads diseases to cattle which in turn constraint the live animal export and decrease the requirement of Ethiopia's livestock in import countries. The results of injury, no isolation, feed disorder, improper storage of feed, problems in the farm including scarcity of materials, absence of proper vaccination and contact of species of animals that were not the member of the species those in feedlot were significant reason in study area. When effectively managed these components meet the principle biosecurity objective of preventing or minimizing cross-contamination of body fluids (feces, urine, saliva, respiratory secretions, etc.) between animals, animals to feed and animals to equipment. These results are in association with the results of Alemayehu and Leta (2014), who reported 87.1\% feedlot owners practiced All-in/All-out management system, almost none of them clean and disinfect the unit between subsequent herds/flock regularly. Sobsey et al. (2003) indicated that manure and other wastes (such as respiratory secretions, urine and sloughed feathers, fur or skin) of various livestock animals often contain high concentrations pathogens which are capable of persisting for days to weeks to months, depending on the pathogen, the medium and the environmental conditions. FMD virus may persist for over 1 year in contaminated premises (Radostits et al., 2006). LSD virus is also remarkably stable and surviving for long periods at ambient temperature, especially in dried scabs (Rovid, 2008).

OIE's objective (Bousfield and Brown, 2011) said that world trade was save guarded by publishing health standards for international trade in animal and animal products. So our country should work hard on this area in order to compete with world regarding animal trade. But now the livestock export from Ethiopia is restricted only to Middle East. During my study period I have seen that the animals those stay in quarantine after they finish their fattening time but because of unavailability market (decrement of requirement by importer country) that animals still stayed in feedlot and expense additional costs to owner.

According to the secondary data collected Ethiopia has not engaged in livestock trade in study area than that of previous. Ethiopia has a number of livestock value chain market opportunities that if realized will power the growth of the livestock industry and value chain as well as the overall economy. As Elisabeth (2010) Ethiopia has some important comparative advantages in the Middle Eastern livestock and meat markets. Without an organized plan for preparing export quality livestock, Ethiopia would not be able to expand its market or even sustain current level of export.

Live animal exports are subject to periodic interruptions from bans imposed by importing countries due to disease outbreaks. Ethiopian livestock imports were banned by one or more import Middle East countries. This occurred a total of seven times during the last three decades. As live animal exporters are small businesses, this adds to instability due to their lack of working capital, which in turn constraints expansion (ILRI, 2013).

In order to overcome these challenges and increase in-country value addition, the Ethiopian Government is committed to supporting animal exports. Yet exports remain small in volume, constrained by inefficiencies in purchasing, poor animal handling and inadequate facilities at the export level. These factors all contribute to low quality and unreliable supply which are the major complaints of exporters regarding Ethiopian livestock.

\section{CONCLUTION}

Export programs of animals still incorporate a formal quarantine period in order to effectively prevent livestock 
disease introduction and spread between feedlots due to management and biosecurity problems activities. This study in one hand has been identified the very low biosecurity measures in export oriented feedlots. In order to eliminate the possibility of spreading animal disease into importing countries, quarantine inspectors will routinely apply quarantine guideline to observe, isolate, treat and test export animals coming from various parts of the country. The introduction and spread of diseases in the quarantine station of animals demonstrates the need for additional and updated regulations that can safeguard the country's livestock from being banned by importing countries.

\section{ACKNOWLEDGMENT}

We would like to acknowledge all the three feedlots operators and owners in and around Adama town for their cooperation during the whole survey. We would also very grateful to Haramaya University College of Veterinary Medicine for material and economic support during the study periods. Finally, we grateful Ethiopian livestock traders' association Adama branch for their provision of valuable information for our study.

Conflict of Interest

The authors have not declared any conflict of interest.

\section{REFERENCES}

Addisu, A. 2012. Beef and feed value chain study in Adama district. EIAR, Debrezeit Agricultural Research Center, Ethiopia.

Aklilu,Y. 2008. Livestock marketing in Kenya and Ethiopia: Review of policies and practice. Feinstein International Center, AA.

Alemayehu, G. and Leta, S. 2014. Biosecurity practices in centeral Ethiopian cattle feedlots: Its implication for live cattle export. International Journal of Livestock Production; 5(11): 181-187.

Alemayehu, G, Zewde, G, Admasu, B. 2012. Risk assessment of lumpy skin diseases in Borena bull market chain and its implication for livelihoods and international trade. Trop. Anim. Health. Pro. 45: 1153-1159.

Alemayehu, G. 2012. Risk assessment of prioritized trans-boundary disease in Borena bull market chain and its implication for international trade. College of Veterinary Medicine and Agriculture, Addis Ababa University (MSc Thesis).

Ausvetplan, 1996. Austeralian veterinary emergency plan enterprise manual animal quarantine stations.Agriculture and resource management council of Australia and Newzeland.Common wealth of Australia and each of its status and Territories.Canbera, Australia.

Belachew, H, Dugasa, D. 2006. Rapid assessment of status of live animal and meat transport of export abattoirs, un published report, SPS-LMM program.

Bousfield, B,Brown, R. 2011. OIE- the World Organization for Animal Health.Veterinary bulletin-Agriculture and, Fisheries and conservation department newsletter. 1(5): 3-7.

Carlson, K. 1998. Biosecurity Profit for the Taking. Good Management Practices for Controlling Infectious Diseases, Dairy Today Supplement, Agri-education, Inc. Dairy Quality Assurance Center.

Desta,T. 2011. Export requirements for meat and live small ruminants. Technical bulletin, $\mathbf{4 4}$

Elisabeth, F. 2010. End market analysis of Ethiopian livestock and meat. A desk study, micro report 164.

Getachew, L. 2008. Live animal and meat export value chains for selected areas in Ethiopia. Constraint and opportunities for enhancing meat export.

Grant, D. 1998. Biosecurity basics for cattle operations and good management for controlling infectious diseases.

Hailamariam, T. 2008. Ethiopia sanitary and phytosanitary standards and livestock and meat marketing program. Live animal and meat export value chains for selected areas in Ethiopia

Hussein, A. 2010. Livestock trade in the Kenyan, Somali and Ethiopian borderlands. Africa programmed. Catham house (the Royal Institute of International affairs), London.

ILRI. 2013. Study of the Ethiopian live cattle and beef value chain. Research program on policies, inistitutions and markets.

Karl, M. 2008. Enabling livestock product export from Ethiopia. Understand the costs, sustainability and poverty reduction implications of sanitary and phytosanitary compliance. Final report for the Texas Agricultural experiment station. Texas and $\mathrm{M}$ university.

MOA. 2010. Quarantine station operation Guide line. Ministry of Agriculture Animal and plant heath Regulatory directorate, Addis Ababa, Ethiopoia.

Rovid, SA. 2008. Lumpy Skin Disease. The center for food security and public health, Iowa State University. College Veterinary Medicine. http://www.cfsph.iastate.edu. Accessed at April 2012.

Sobsey, MD. Khatib, LA. Hill, VR. Alocilja, E. Pillai, S. 2003. Pathogens in Animal Wastes and the impacts of waste management practices on their survival, transport and fate. White paper summaries.

Spencer, J. 1996. Development of composting and management strategies for elimination of animal pathogens and assay systems to monitor effectiveness, Canadian Food Inspection Agency. 
Tambi, M. 2002. Financial support to Animal health services: case studies from Cameroon, Ethiopia, Mali, Kenya, Tanzania and Uganda, AU-Interafrican for Animal Resources.

USAID, 2013. End market analysis for meat/live animals leather and leather products, dairy products value chains.US Agency for international development Agriculture growth program-Livestock market development.

Wallace, R. 1996. Consider Biosecurity Steps When Expanding Herd. University of Illinois, College of Veterinary Medicine. 